\title{
MODEL PEMBELAJARAN THINK PAIR SHAREBERMEDIA KOMIK UNTUK MENINGKATKAN MOTIVASI BERPRESTASI DAN HASIL BELAJAR BAHASA INGGRIS SISWA
}

\author{
Kadek Agus Jaya Pharhyuna A.M. \\ SMK Negeri 1 Singaraja \\ agusjayapharhyuna@gmail.com
}

\begin{abstract}
Abstrak
Penelitian ini bertujuan untukmeningkatkan motivasi berprestasi dan hasil belajar Bahasa Inggris siswa melalui penerapan model pembelajaran Think Pair Sharebermedia komik. Penelitian ini adalah penelitian tindakan kelas yang dilaksanakan dalam dua siklus. Subjek penelitian ini adalah siswa kelas XI UPW A SMK Negeri 1 Singaraja tahun pelajaran 2017/2018. Data motivasi berprestasisiswa diperoleh dengan menggunakan angket sedangkan data prestasi belajar Bahasa Inggris siswa diperoleh dengan menggunakan tes.Hasil analisis analisis menunjukkan: (1) motivasi berprestasi siswa meningkat dari skor rata-rata 67,53\% pada siklus I menjadi 75,66\% pada siklus II; (2) hasil belajar Bahasa Inggris siswa meningkat dari skor rata-rata 7,18 pada siklus I menjadi 7,61 pada siklus II. Dapat disimpulkan bahwa model pembelajaran Think Pair Sharebermedia komik dalam pelajaran Bahasa Inggris dapat meningkatkan motivasi berprestasi siswa dan hasil belajar. Beberapa saran-saran yang ditujukan kepada guru dan pemerintah juga dibahas.
\end{abstract}

Kata kunci : Think Pair Share, motivasi berprestasi

\begin{abstract}
This study aimed atimproving students' achievement motivation and improving students' English through the implementation of Think Pair Sharelearning model assisted with comic media. This study was a classroom action research that was conducted in two cycles. The subjects were the eleventh year UPW A students of SMK Negeri 1 Singaraja in the academic year 2017/2018. The data of students' achievement motivation were obtained by using questionnaires, while English learning achievement data were obtained using English test. The analysis result showed (1) there was an improvement on students' achievement from $67.53 \%$ in average in cycle I became $75.66 \%$ in cycle II; (2) there was an improvement in students' English achievement from 7.18 in average in cycle I became 7.61 in cycle II. It can be concluded that Think Pair
\end{abstract}


Sharelearning model with comic media can improve students' achievement motivation and students' learning achievement in English. Some suggestions to teachers and government are discussed.

Keywords : Think Pair Share, achievement motivation

\section{Pendahuluan}

Bahasa Inggris merupakan salah satu mata pelajaran yang masih menentukan dalam kelulusan siswa di Sekolah Menengah Kejuruan. Setelah siswa lulus di tingkat Sekolah Menengah Kejuruan, mereka juga dituntut untuk menggunakan Bahasa Inggris baik tertulis maupun lisan di dunia kerja atau dunia industri. Dengan demikian, kemampuan siswa dalam memahami dan menguasai Bahasa Inggris memegang peranan yang sangat signifikan utuk bisa lulus dalam Ujian Nasional serta mampu bersaing nantinya di dunia kerja. Hal ini sejalan dengan Pasal 37 Ayat (1) dalam Undang-undang Sistem Pendidikan Nasional No 20 Tahun 2003 (Depdiknas, 2003) menyebutkan bahwa bahasa asing terutama Bahasa Inggris merupakan bahasa internasional yang sangat penting kegunaannya dalam pergaulan global.

Di tingkat satuan pendidikan Sekolah Menengah Kejuruan, silabus mata pelajaran Bahasa Inggris sudah disusun sedemikian rupa yang secara umum penekanannya pada penggunaan ungkapan-ungkapan atau expressions yang nantinya digunakan dalam pekerjaan sehari-hari. Selanjutnya, Kementerian Pendidikan Nasional (2010) mncantumkan pada lampiran Peraturan Menteri Pendidikan Nasional nomor 46 tahun 2010 tanggal 31 Desember 2010 terkait dengan Standar Kompetensi Lulusan Ujian Nasional baik bahwa pada listening section khususnya pada question response maupun reading section untuklebih menekankan pada penggunaan ungkapan-ungkapan kegiatan sehari-hari.

Untuk mendukung Standar Kompetensi Lulusan Ujian Nasional tersebut maka Sekolah Menengah Kejuruan Negeri 1 Singaraja berupaya untuk meningkatkan Kriteria Ketuntasan Minimal mata pelajaran Bahasa Inggris pada setiap tahunnya. Usaha tersebut didukung dengan adanya peningkatan intake siswa melalui proses seleksi yang ketat lewat Tes Potensi Akademik pada mata 
pelajaran Bahasa Inggris. Di samping itu, sekolah berupaya meningkatkan fasilitas pendukung sarana dan prasarana beserta sumber daya manusia yang terlatih melalui pendidikan dan pelatihan yang diprogramkan setiap tahunnya.

Bahasa Inggris yang diterapkan di Sekolah Menengah Kejuruan tentu saja harus mengarahkan siswa untuk mampu menggunakannya dalam dunia kerja bukan sekadar lulus dalam ujian nasional. Jurusan Usaha Perjalanan Wisata di SMKN 1 Singaraja memiliki peranan penting dalam perkembangan kepariwisataan di Bali. Terkait dengan itu, siswa harus dibekali Bahasa Inggris yang merupakan persyaratan pokok dalam memperoleh pekerjaan di dunia pariwisata. Harapan ini juga didukung oleh hasil kuesioner yang disebarkan kepada siswa dimana mereka cenderung belajar Bahasa Inggris untuk memperoleh pekerjaan.

Pentingnya belajar Bahasa Inggris juga dihadapkan pada kenyataaan bahwa Indonesia akan menghadapi Asian Free Trade Association (AFTA) tahun 2015 kedepan. Ini akan berdampak pada persaingan kerja di dunia global dan pendominasian berbagai lapangan kerja. Sebagai bentuk komunikasi yang diharapkan dalam era globalisasi adalah bahasa yang bisa dipahami secara internasional, dalam hal ini adalah Bahasa Inggris. Untuk itu, guru Bahasa Inggris memiliki peran yang sangat penting dalam mengupayakan suatu pembelajaran yang dapat meningkatkan motivasi siswa dengan pembelajaran yang terintegrasi dan komunikatif.

Fakta lain terkait dengan kesiapan kerja generasi muda disampaikan oleh ILO International Labour Organization/ILO (2012) dinyatakan bahwa jumlah pengangguran usia produktif 4,6 kali lebih banyak dibandingkan pengangguran orang dewasa di Indonesia. Pengangguran ini tentu saja disebabkan oleh minimnya tenaga terampil yang dimiliki oleh masyarakat, khususnya di bidang komunikasi dan peguasaan informasi dan teknologi. Mengingat informasi dan teknologi dikomunikasikan dengan bahasa global, maka Bahasa Inggris sangat diperukan untuk menunjang keterampilan lainnya.

Guru Bahasa Inggris sangat diharapkan dapat meningkatkan kemampuan Bahasa Inggris siswa. Upaya yang dilakukan guru Bahasa Inggris diharapkan sejalan dengan apa yang tertuang dalam Permendiknas RI Nomor 22 Tahun 2006 
tentang Standar Isi bahwa pada Level Elementry bahwa setiap keterampilan berbahasa memiliki tujuan bagaimana siswa dapat mengungkapkan makna secara lisan maupun tulisan dalam wacana interpersonal dan transaksional, secara formal maupun informal, dalam bentuk penyampaian permintaan dan perintah yang berkaitan dengan pekerjaan.

Akan tetapi ada beberapa kenyataan yang tidak bisa dipungkiri sebagai penyebab timbulnya permasalahan-permasalahan dalam pembelajaran Bahasa Inggris khususnya pemahaman ungkapan-ungkapan yang digunakan dalam komunikasi sehari-hari, diantaranya adalah: pertama, adanya pengurangan jam pelajaran Bahasa Inggris di SMK yang awalnya enam jam perminggu menjadi empat jam perminggu terkait dengan Surat Keputusan Bersama Lima Menteri (Menteri Pendidikan Nasional, Meneg PAN dan Reformasi Birokrasi, Mendagri, Menteri Keuangan, dan Menteri Agama), Nomor 05/X/PB/2011, Nomor SPB/03/M.PAN-RB/10/2011, Nomor 48 Tahun 2011, Nomor 158/PMK.01/2011, dan Nomor 11 Tahun 2011, tentang Penataan dan Pemerataan Guru Pegawai Negeri Sipil. Hal ini tentu saja berdampak pada kurangnya durasi latihan siswa dalam belajar Bahasa Inggris di kelas; kedua, hasil observasi dan kuesioner menunjukkan bahwa guru kurang memperhatikan kerja kelompok dalam proses pembelajaran. Pembelajaran hanya dilakukan satu arah, dimana guru sebagai sumber belajar. Sementara itu, siswa hanya melakukan pencatatan materi yang diberikan oleh guru. Kadang-kadang siswa mengerjakan Lembar Kerja Siswa dan guru keliling memantau aktivitas siswa; ketiga, hasil observasi dan kuesioner yang disebarkan ke siswa maupun guru menunjukkan bahwa guru hampir jarang menggunakan media yang menarik bagi siswa. Media yang digunakan kadangkadang tidak berfungsi dengan baik atau sebatas pengganti papan tulis dengan menggunakan $L C D$; keempat, hasil wawancara juga menunjukkan bahwa di dalam memberikan penilaian, guru cenderung masih menerapkan penilaian konvensional yang menciptakan kecemasan dan ketakutan bagi siswa akan hukuman dan rasa malu yang ditanggung bila memperoleh nilai yang buruk. Hal ini sama sekali tidak memotivasi siswa dalam meraih prestasi di kelas maupun bersaing dengan teman-temannya di jurusan atau kelas yang berbeda. 
Upaya-upaya yang telah dilakukan untuk mengatasi permasalahanpermasalahan tersebut adalah dengan memberikan pelajaran tambahan berupa kursus Bahasa Inggris atau diskusi-diskusi di luar jam pelajaran sehingga siswa bisa terus berlatih menggunakan Bahasa Inggris dalam arahan guru. Melalui kursus dan diskusi, siswa memiliki kesempatan untuk berlatih dengan guru Bahasa Inggris, teman sejawat, ataupun penutur asli Bahasa Inggris. Terkait dengan permasalahan yang bersumber dari guru, penulis melakukan diskusidiskusi dengan teman sejawat dalam kegiatan Musyawarah Guru Mata Pelajaran ataupun workshop-workshop tertentu.

Akan tetapi, apa yang telah dilakukan tersebut belum menuai hasil yang diharapkan. Hal ini bisa dilihat dari hasil belajar Bahasa Inggris dari tahun ke tahun sebagai berikut.

Tabel 01. Data hasil belajar Bahasa Inggris siswa kelas XI UPW A

\begin{tabular}{ccc}
\hline Tahun Ajaran & Rata-rata & Ketuntasan Belajar \\
$2014 / 2015$ & 7,05 & $45,45 \%$ \\
$2015 / 2016$ & 5,33 & $34,38 \%$ \\
$2016 / 2017$ & 6,10 & $10,53 \%$ \\
\hline & \multicolumn{2}{c}{ (Sumber: Data hasil belajar SMKN 1 Singaraja) }
\end{tabular}

Hal tersebut menunjukkan bahwa hasil belajar Bahasa Inggris yang dicapai siswa masih jauh dari harapan, mengingat tuntutan kurikulum terkait dengan hasil belajar Bahasa Inggris rata-rata minimal 7,5 dan ketuntasan klasikal minimal 75\%. Sehubungan dengan permasalahan tersebut, peneliti menggunakan model pembelajaran Think Pair Share yang biasa disingkat Think Pair Sharebermedia komik sebagai upaya meningkatkan motivasi berprestasi dan hasil belajar Bahasa Inggris siswa kelas XI UPW A SMK Negeri 1 Singaraja Tahun Pelajaran $2017 / 2018$.

Model pembelajaran Think Pair Sharemerupakan pembelajaran kooperatif yang memberi siswa waktu banyak untuk berpikir, menjawab permasalahan dan saling membantu satu sama lainnya. Penerapan model pembelajaran ini diharapkan mampu meningkatkan partisipasi seluruh kelas yang awalnya hanya didominasi oleh beberapa orang siswa saja. Model pembelajaran ini juga memberikan kesempatan kepada siswa untuk bekerja sendiri serta bekerja sama 
dengan orang lain. Dengan sharing maka siswa akan bisa bertukar pikiran, ide, dan pendapat sehingga mereka bisa berbagi pengetahuan.

Komik sebagai media pembelajaran akan mampu menimbulkan rasa senang dan gembira dalam pembelajaran, sehingga akan mengurangi kecemasan siswa dalam mengikuti proses pembelajaran Bahasa Inggris. Selain itu, siswa akan termotivasi dalam mengikuti proses pembelajaran dengan menggunakan media komik. Dr. Glen Downey mengatakan bahwa komik dan novel grafis dapat menjadi alat penting untuk mengembangkan keterampilan keaksaraan dasar para siswa. komik dan novel grafis membantu para siswa dalam mengembangkan membaca, menulis, maupun menyimak. Komik berbahasa Inggris ini juga meningkatkan penguasaan sejumlah kosakata dan memproduksinya menjadi kalimat-kalimat yang nantinya disampaikan baik secara lisan maupun tulisan.

Dengan penerapan model pembelajaran Think Pair Sharebermedia komik diharapkan dapat meningkatkan motivasi berprestasi siswa dan hasil belajar Bahasa Inggris mereka. Motivasi berprestasi sangat penting dalam proses pembelajaran karena motivasi itu sendiri dapat menciptakan prestasi diri baik yang belum ataupun yang pernah dicapai sebelumnya. Motivasi juga dapat membandingkan prestasi yang diraih seorang siswa dengan prestasi yang diraih oleh siswa lainnya. Penelitian yang dilakukan oleh Utami (2011) membuktikan bahwa motivasi berprestasi dan penilaian teman sejawat dapat meningkatkan keterampilan menulis siswa.Dengan tumbuhnya motivasi berprestasi siswa melalui model pembelajaran Think Pair Shareyang dipadukan dengan penggunaan media komik maka hasil belajar Bahasa Inggris siswa akan meningkat sesuai dengan target yang perlu dicapai. Di samping itu, penelitian Monthe dan Panjaitan (2016) menunjukkan adanya hasil belajar Bahasa Inggris yang lebih tinggi pada siswa yang memiliki motivasi berprestasi tinggi dibanding yang rendah, dan strategi pembelajaran serta motivasi berprestasi terbukti dapat meningkatkan hasil belajar siswa. Pencapaian hasil belajar ini akan memberikan dampak positif bagi siswa yang bersangkutan maupun tujuan pendidikan nasional secara umum.

Berdasarkan latar belakang dan identifikasi masalah yang telah diuraikan, terdapat dua masalah yang diupayakan pemecahannya melalui classroom action 
research, yaitu: (1) Sejauh manakah penerapan model pembelajaran Think Pair Share bermedia komik dapat meningkatkan motivasi berprestasi siswa kelas XI UPW SMK Negeri 1 Singaraja? (2) Sejauh manakan penerapan model pembelajaran Think Pair Share bermedia komik dapat meningkatkan hasil belajar Bahasa Inggris siswa kelas XI UPW A SMK Negeri 1 Singaraja?

Tujuan umum dilakukannya penelitian ini adalah untuk mengembangkan model pembelajaran inovatif, yaitu Think Pair Sharesekaligus penggunaan komik sebagai media dalam pembelajaran. Sementara itu, tujuan khusus penelitian ini dapat dirumuskan sebagai berikut. (1) Meningkatkan motivasi berprestasi siswa kelas XI UPW A SMK Negeri 1 Singaraja tahun pelajaran 2017/2018 melalui penerapan model pembelajaran Think Pair Sharebermedia komik. (2) Meningkatkan hasil belajar siswa kelas XI UPW A SMK Negeri 1 Singaraja tahun pelajaran 2017/2018 melalui penerapan model pembelajaran Think Pair Sharebermedia komik.

Lebih lanjut, penelitian ini diharapkan memiliki manfaat bagi siswa dimana penerapan model pembelajaran Think Pair Share bermedia komik diharapkan dapat membantu siswa dalam memahami dan menggunakan Bahasa Inggris dalam komunikasi sehari-hari baik selama masih menjadi siswa maupun bila sudah memasuki dunia kerja. Di samping itu, bagi guru, penerapan model pembelajaran Think Pair Share bermedia komik dapat memberikan pengetahuan teoritik dan pengalaman praktik sebagai upaya mengemas pembelajaran inovatif. Penelitian ini juga memberikan kontribusi terhadap kemajuan sekolah terkait dengan pemenuhan standar proses di samping memberikan wawasan tentang pembelajaran inovatif.

Sebagai sebuah model, Think-Pair-Share merupakan salah satu model pembelajaran kooperatif yang dirancang untuk empengaruhi pola interaksi siswa. Model ini juga disebut dengan berpikir-berpasangan-berbagi. Model belajar ini, mula-mula dikembangkan oleh Frank Lyman dkk dari Universitas Maryland. Ini merupakan cara yang efektif untuk mengelola pola diskusi didalam kelas, strategi ini menentang asumsi bahwa seluruh resitasi dan diskusi perlu dilakukan didalam setting kelompok dimana guru mengajukan pertanyaan kepada seluruh kelas dan siswa memberikan jawaban dan ditunjuk.Pembelajaran Think-Pair- 
Share(TPS)memiliki prosedur yang ditetapkan secara implisit untuk membersiswa waktu lebih banyak untuk berpikir, menjawab permasalahan dan saling membantu satu sama lain. Prosedur tersebut telah disusun dan dibentuk sedemikian rupa sehingga dapat memberikan waktu yang lebih banyak kepada siswa untuk dapat berpikir dan merespon yang nantinya akan membangkitkan pertisipasi siswa.

Model pembelajaran Think Pair Share dikembangkan oleh Frank Lyman, dkk dari Universitas Maryland tahun 1981 (Huda, 2011). Think Pair Share adalah pembelajaran yang memberi siswa kesempatan untuk bekerja sendiri dan bekerjasama dengan orang lain. Dalam hal ini, guru sangat berperan penting untuk membimbing siswa melakukan diskusi, sehingga terciptanya suasana belajar yang lebih hidup, aktif, kreatif, efektif dan menyenangkan (Lie, 2008). Model pembelajaran tipe Think Pair Share merupakan pembelajaran kooperatif sederhana yang memberi siswa banyak waktu untuk berpikir, menjawab, bekerja sendiri dan saling membantu satu sama lain.

Langkah-langkah atau sintaks dalam model pembelajaran Think- PairShare terdiri dari 5 langkah, dengan tiga langkah utama sebagai ciri khas yaitu think, pair dan share. Kelima tahapan pembelajaran dalam model pembelajan Think-Pair-Share sebagai berikut:

Tabel 2.1 Sintaks model pembelajaran think-pair-share

\begin{tabular}{|c|c|c|}
\hline $\mathrm{No}$ & Tahap & Peran Guru \\
\hline 1 & $\begin{array}{l}\text { Tahap } 1 \text { Pendahuluan } \\
\text { Guru menyampaikan } \\
\text { pertanyaan }\end{array}$ & $\begin{array}{l}\text { Aktivitas guru melakukan apersepsi, } \\
\text { menjelaskantujuan pembelajaran } \\
\text { danmenyampaikan pertanyaan yang } \\
\text { berhubungan dengan materi pelajaran }\end{array}$ \\
\hline 2 & $\begin{array}{l}\text { Tahap } 2 \\
\text { Think }\end{array}$ & $\begin{array}{l}\text { Aktivitas guru memberikan kesempatan kepada } \\
\text { siswa untuk memikirkan jawaban dari permasalahan } \\
\text { yang disampaikan guru. Langkah ini dapat } \\
\text { dikembangkan dengan meminta siswa untuk } \\
\text { menuliskan hasil pemikiran merekamasing-masing. }\end{array}$ \\
\hline 3 & $\begin{array}{l}\text { Tahap } 3 \\
\text { Pair }\end{array}$ & $\begin{array}{l}\text { Aktivitas guru mengorganisasikan siswa untuk } \\
\text { berpasangan dan memberikan kesempatan pada } \\
\text { siswa untuk mendiskusikan jawaban yang menurut }\end{array}$ \\
\hline
\end{tabular}


mereka paling benar atau saling meyakinkan. Guru

memotivasi siswa untukaktif dalam diskusi

pasangan.

4 Tahap 4

Share

5 Tahap 5 Penutup
Aktivitas siswa mempresentasikan jawaban atau

pemecahan masalah secara individual atau berpasangan di depan kelas.

Aktivitas guru membantu siswa untuk melakukan

refleksi atau evaluasi terhadap hasil pemecahan

masalah yang telah mereka

diskusikan.

Sementara itu, menurut Ibrahim (2000) dalam pembelajaran yang menerapkan model pembelajaran kooperatif tipe Think Pair Share terdapat 3 tahap yang sangat penting, yaitu: tahap pertama adalah thinking (berpikir), dalam hal ini, pembelajaran diawali dengan guru mengajukan pertanyaan atau isu yang berhubungan dengan pelajaran untuk dipikirkan oleh siswa. Guru memberi kesempatan kepada siswa secara mandiri untuk memikirkan jawabannya. Pada tahap kedua, pairing (berpasangan), yaitu meminta siswa berpasangan. Siswa yang telah berpasangan diberi kesempatan mendiskusikan apa yangtelah dipikirkan. Diharapkan diskusi ini dapat memperdalam makna dari jawaban yang telah dipikirkan.Tahap ketiga, sharing (berbagi), yaitu meminta kepada pasangan siswa untuk berbagi dengan seluruh kelas mengenai hasil diskusi yang telah dilakukan. Keterampilan berbagi dalam kelas dapat dilakukan dengan menunjuk pasangan yang secara sukarela bersedia melaporkan hasil kerja kelompoknya atau bergiliran pasangan demi pasangan melaporkan hasil kerja.Kegiatan berpikirberpasangan-berbagi dalam Think Pair Share memberikan keuntungan, diantaranya siswa secara individu dapat mengembangkan pemikirannya masingmasing karena adanya waktu berpikir, sehingga kualitas jawaban juga dapat meningkat. Jumlah anggota kelompok yang kecil mendorong setiap anggota untuk terlibat secara aktif, sehingga siswa yang jarang atau bahkan tidak pernah berbicara di depan kelas paling tidak memberikan ide atau jawaban karena pasangannya.Rochmad dan Sugiharti (2015) menyatakan bahwa penerapan Think Pair Sharedalam media Mouse Mischief dapat meningkatkan kemampuan 
pemecahan soal matematika dan aktivitas pembelajaran ssiwa. Hal senada juga disampaikan oleh Syafii(2018) bahwa penggunaan strateg Think Pair Share dapat meningkatkan keaktifan dan kemampuan berbicara Bahasa Inggris mahasiswa.

Di samping penggunaan model pembelajaran Think Pair Share, penggunaankomik juga memberikan peranan dalam penelitian ini. "Komik" sesungguhnya berasal dari bahasa Inggris comic, kōmikos (Yunani) yang berarti: lucu. Istilah ini sudah muncul sekitar abad ke-16. Pada awalnya, komik ialah gambar-gambar yang "berbicara" tentang hal-hal yang lucu. Di samping itu, komik pada umumnya memiliki dua unsur penting, yaitu gambar dan narasi dalam bentuk teks". Maka dapat diketahui bahwa komik adalah suatu buku cerita yang memiliki karakteristik khusus dengan gambar dan cerita lucu. Komik juga merupakan salah satu sarana yang dapat digunakan untuk menyampaikan pesan kepada para pembacanya.

Lebih lanjut, komik memiliki berbagai macam jenis dalam penyajiannya berdasarkan bentuk, genre, dan lain-lainnya. Jenis komik berdasarkan bentuknya terdiri dari komik strip (comic strips), buku komik (comic book), novel grafis (graphic novel), dan komik komplikasi”. Sedangkan menurut Trimo (1997) komik dibedakan menjadi 2, yaitu:1) komik strip (comic strips), suatu bentuk komik yang terdiri dari beberapa lembar bingkai kolom yang dimuat dalam suatu harian atau majalah, biasanya disambung ceritanya; dan 2) buku komik (comic book), komik yang dikemas dalam bentuk buku dan satu buku biasanya menampilkan sebuah cerita yang utuh.

Dengan pembelajaran beredia komik, motivasi berprestasi siswa akan meningkat. Dalam hal ini, diketahui bahwa bahwa motivasi berprestasi adalah sifat (trait) umum yang selalu ditunjukkan siswa di berbagai bidang. Sebaliknya, sebagian besar teoritikus kontemporer percaya bahwa motivasi berprestasi mungkin agak spesifik terhadap tugas dan peristiwa tertentu. Motivasi berprestasi juga terdiri dari berbagai bentuk yang berbeda, tergantung tujuan spesifik individu. (Ormrod, 2008). Konsep motivasi berprestasi dirumuskan pertama kali oleh Henry Alexander Murray. Murray memakai istilah kebutuhan berprestasi (need for achievement) untuk motivasi berprestasi, yang dideskripsikannya sebagai hasrat atau tendensi untuk mengerjakan sesuatu yang sulit dengan secepat 
dan sebaik mungkin (Purwanto, 2004). Menurut Murray sebagaimana dikuti oleh Winkle (2004) achievement motivation (motivasi berprestasi) adalah daya penggerak untuk mencapai taraf prestasi belajar yang setinggi mungkin demi pengharapan kepada dirinya sendiri.Mc. Clelland (1987) mengatakan bahwa motivasi berprestasi adalah suatu keinginan yang ada dalam diri seseorang yang mendorong orang tersebut untuk berusaha mencapai suatu standar atau ukuran keunggulan. Ukuran keunggulan didapat dengan acuan prestasi orang lain, akan tetapi juga dapat dengan membandingkan prestasi yang dibuat sebelumnya.

Penelitian ini merupakan penelitian tindakan kelas yang sangat penting dilakukan mengingat masih rendahnya hasil belajar dan motivasi berprestasi siswa kelas XI UPW SMK Negeri 1 Singaraja tahun pelajaran 2017/2018. Untuk menjawab permasalahan dalam penelitian ini, maka perlu adanya kerangka berfikir yang logis, yaitu: pertama, model pembelajaran Think Pair Sharesebagai bagian dari pembelajaran kooperatif menyiapkan siswa untuk menyusun ide-ide secara individu, menyampaikan secara berpasangan, kemudian mengungkapkan dihadapan teman yang lainnya. Dengan kegiatan yang dirancang seperti ini, siswa akan lebih aktif dalam pembelajaran Bahasa Inggris. Arah pembelajaran tidak sebatas antara guru dengan siswa tetapi juga siswa dengan siswa lainnya. Dengan bantuan komik sebagai media pembelajaran, siswa akan merasa senang dan rileks dalam mengikuti proses pembelajaran karena siswa pada umumnya memiliki presepsi bahwa komik identik dengan sesuatu yang lucu. Lucu dalam hal ini mencakup segi gambar tokoh yang ditampilkan dan juga konten yang ada pada komik tersebut; dan kedua, disamping meningkatkan hasil belajar Bahasa Inggris siswa, model pembelajaran Think Pair Sharedengan media komik juga meningkatkan motivasi berprestasi siswa. Usaha untuk meningkatkan hasil belajar Bahasa Iggris dipicu oleh keinginan dari siswa itu sendiri dengan adanya penerapan model pembelajaran Think Pair Share, disamping dorongan untuk membandingkan kemampuan diri dengan pasangan kerja siswa dan siswa yang lainnya Konsep tersebut merupakan bagian dari model pembelajaran Think Pair Shareyang dikolaborasikan dengan penggunaan media komik sebagai media pembelajaran. 
Berdasarkan latar belakang dan landasan teoritis yang telah diuraikan di atas, maka rumusan hipotesis tindakannya adalah: 1) dengan menerapkan model pembelajaran Think Pair Sharebermedia komik, motivasi berprestasi siswa kelas XI UPW SMK Negeri 1 Singaraja tahun pelajaran 2017/2018 dapat ditingkatkan; dan 2) dengan menerapkan model pembelajaran Think Pair Sharebermedia komik, hasil belajar Bahasa Inggris siswa kelas XI UPW SMK Negeri 1 Singaraja tahun pelajaran 2017/2018 dapat ditingkatkan.

\section{Metode}

Penelitian ini adalah Penelitian Tindakan Kelas (PTK) menggunakan desain model Kemmis \& McTaggart yang menetapkan setting dua siklus sesuai dengan karakteristik materi. Penelitian pada masing-masing siklus dilaksanakan melalui empat tahapan, yaitu: (1) perencanaan penelitian; (2) pelaksanaan tindakan; (3) observasi/ evaluasi; dan (4) refleksi.

Subjek penelitian ini adalah siswa kelas XI UPW A SMK Negeri 1 Singaraja tahun pelajaran 2017/2018 yang berjumlah 38 orang terdiri dari 17 siswa laki dan 21 siswa perempuan. Objek tindakan dari penelitian ini adalah model pembelajaran Think Pair Share (TPS) bermedia komik, sedangkan objek produk dari penelitian ini adalahmotivasi berprestasi siswa dan hasil belajar Bahasa Inggris siswa. Penelitian ini dilaksanakan pada semester genap tahun pelajaran 2017/2018 di SMK Negeri 1 Singaraja, Jalan Pramuka No. 6 Singaraja.

Keadaan awal siswa terkait motivasi berprestasi dan hasil belajar Bahasa Inggris siswa diperoleh dari nilai siswa, hasil observasi dan wawancara. Dari hasil belajar siswa pada semester sebelumnya, hasil observasi, dan wawancara tersebut maka siswa perlu diberikan treatment berupa model pembelajaran Think Pair Share bermedia komik.

Adapun kegiatan pembelajaran yang dilakukan adalah sebagai berikut. Pada perencanaan tindakan, hal-hal yang perlu dipersiapkan yaitu: (1) menentukan materi ajar; (2) menyiapkan media pembelajaran dalam bentuk serial komik; (3) menyiapkan materi pembelajaran, dalam bentuk dialog/ percakapan; (4) mengatur ruang kelas; (5) menyiapkan Perangkat Pembelajaran (RPP); dan (6) Menyiapkan instrumen penelitian berupa lembar observasi untuk guru dan siswa, 
tes evaluasi belajar siswa, lembar jawaban siswa, dan instrumen motivasi berprestasi.

Pada pelaksanaan tindakan, langkah-langkah yang dilaksanakan pada saat kegiatan belajar mengajar dibagi menjadi tiga tahap, yaitu: (1) tahap pendahuluan dengan kegiatan seperti menginformasikan beberapa materi yang harus diingat kembali oleh siswa sebagai prasyarat dalam mempelajari materi yang akan diberikan, menggali pengetahuan awal peserta didik, dan memaparkan indikator dan tujuan pembelajaran yang ingin dicapai; (2) tahap inti pembelajaran dengan kegiatan seperti menampilkan sebuah slide yang berisi gambar dan percakapan pendek (potongan komik), menggali pengetahuan peserta didik dengan meminta mereka untuk mencermati slide yang telah ditunjukkan kemudian guru mengajukan beberapa pertanyaan (THINK), meminta peserta didik untuk membentuk kelompok dengan teman sebangkunya $(P A I R)$, meminta peserta didik mempresentasikan hasil diskusinya untuk berbagi pendapat kepada peserta didik lain di depan kelas. (SHARE), dan mengomentari penampilan peserta didik, menunjukkan kekurangan dan kelemahan peserta didik ketika melakukan presentasi; dan (3) tahap penutup dengan kegiatan seperti membuat rangkuman materi dengan bantuan guru, memberikan tes kecil yang diselesaikan secara individual, dan memberikan PR.

Data yang dikumpulkan dalam penelitian ini terdiri atas: (1) data motivasi berprestasi siswa yang dikumpulkan dengan menggunakan lembar kuesioner motivasi berprestasi pada tiap siklus; dan (2) data hasil belajar Bahasa Inggris siswa dikumpulkan pada setiap akhir siklus. Peningkatan hasil belajar siswa diperoleh dengan membandingkan hasil (ketuntasan klasikal dan daya serap) di siklus I dan siklus II.

Data motivasi berprestasi dianalisis secara deskriptif. Kriteria penggolongan motivasi berprestasi disusun berdasarkan mean ideal (MI) dan standar deviasi ideal (SDI). penghitungan rata-rata persentase siswa yang memenuhi indikator motivasi berprestasi siswa untuk kemudian dikategorikan dengan pedoman berikut. 
Tabel 02. Pedoman Kategori Motivasi Berprestasi Siswa

\begin{aligned} & \hline \multicolumn{1}{c}{ Rentangan skor } \multicolumn{1}{c}{ Kategori } \\ & \hline $\mathrm{MI}+1,5 \mathrm{SDI} \leq \mathrm{MB}$ Sangat tinggi \\ & $\mathrm{MI}+0,5 \mathrm{SDI} \leq \mathrm{MB}<\mathrm{MI}+1,5 \mathrm{SDI}$ Tinggi \\ & $\mathrm{MI}-0,5 \mathrm{SDI} \leq \mathrm{MB}<\mathrm{MI}+0,5 \mathrm{SDI}$ Sedang \\ & $\mathrm{MI}-1,5 \mathrm{SDI} \leq \mathrm{MB}<\mathrm{MI}-0,5 \mathrm{SDI}$ Rendah \\ & $\mathrm{MB}<\mathrm{MI}-1,5 \mathrm{SDI}$ Sangat rendah \\ & \hline\end{aligned}

(Sumber: Sugiono, 2010:94)

Harapan yang ingin dicapai siswa pada siklus I terkait motivasi berprestasi adalah perolehan rata-rata dengan kategori tinggi. Bila target tersebut tidak tercapai maka siswa akan diberikan perlakuan yang berbeda pada siklus II dengan melihat kelemahan-kelemahan pada siklus I.

Data hasil belajar Bahasa Inggris siswa dikumpulkan dengan mencari ketuntasan belajar siswa (individual), ketuntasan belajar klasikal. dan daya serap. Ketuntasan belajar siswa (individual) ditentukan sendiri oleh masing-masing sekolah yang dikenal dengan istilah Kriteria Ketuntasan Minimal (KKM), dengan berpedoman pada tiga pertimbangan, yaitu: kemampan setiap peserta didik, fasilitas (sarana), dan daya dukung lainnya (Trianto, 2010:241). KKM untuk pelajaran Bahasa Inggris kelas XI UPW A di SMK Negeri 1 Singaraja adalah 72. Sementara itu, suatu kelas dikatakan tuntas belajarnya (ketuntasan klasikal) jika dalam kelas tersebut terdapat $\leq 85 \%$ siswa yang telah tuntas belajarnya.

\section{Hasil dan Pembahasan}

Motivasi berprestasi siswa kelas XI UPW A SMK Negeri 1 singaraja setelah diberikan perlakuan berupa penerapan model pembelajaran Think Pair Sharebermedia komik pada siklus I menunjukkan rerata 67,53\%. Secara keseluruhan motivasi berprestasi siswa pada siklus I ini berada pada kategori “Tinggi”. Harapan yang ingin dicapai terkait motivasi berprestasi ini adalah "Tinggi". Dengan demikian, penerapan model pembelajaran Think Pair Sharebermedia komik pada siklus I sudah memenuhi kriteria tersebut. Sementara itu, pada siklus II motivasi berprestasi siswa menunjukkan rerata persentase $75,66 \%$. Meskipun ada perbedaan persentase antara siklus I dan siklus II, namun 
secara keseluruhan motivasi berprestasi siswa pada kedua siklus tetap berada pada kategori "Tinggi". Perbandingan motivasi berprestasi siswa pada siklus I dan siklus II terlihat pada gambar diagram batang berikut.

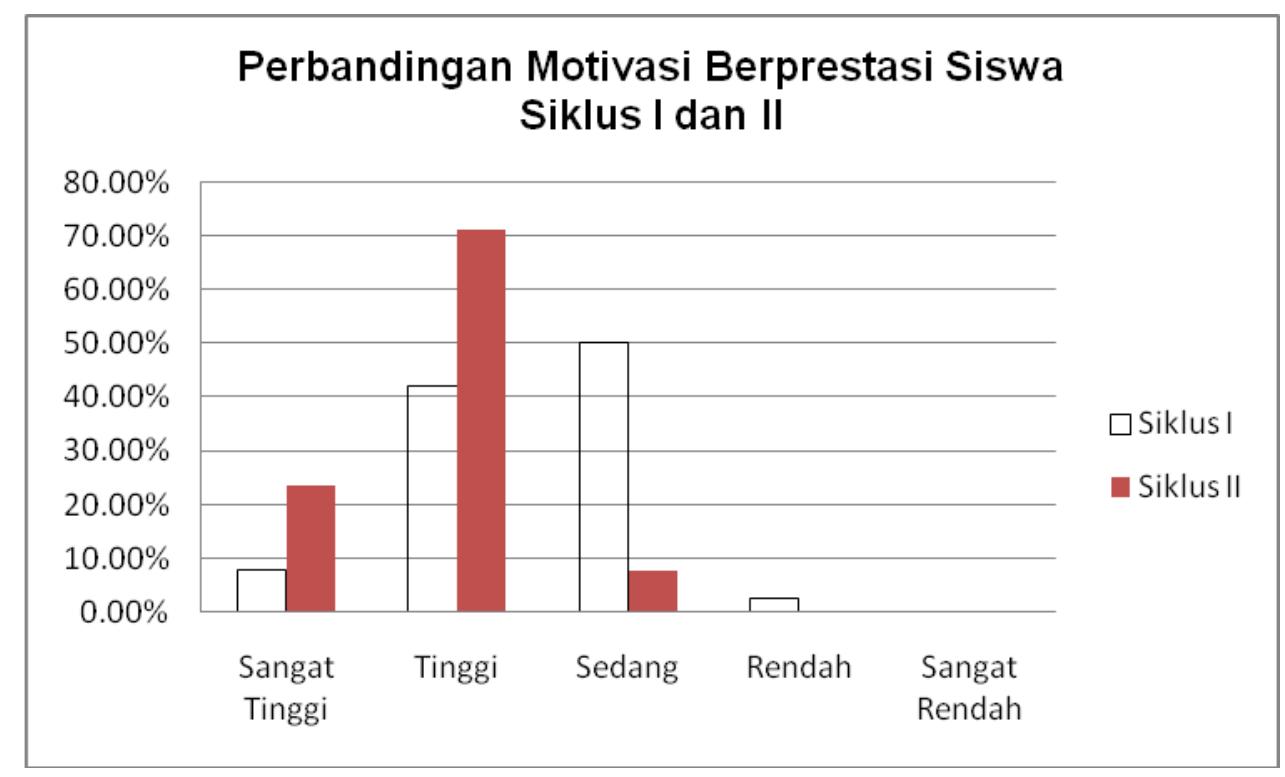

Gambar 01. Diagram Batang Perbandingan Motivasi berprestasi Siklus I dan II

Materi yang diajarkan pada siklus I adalah "how to offer an invitation" dan"bargaining". Berdasarkan hasil analisis data diketahui rata-rata hasil belajar siswa 7,18 dengan ketuntasan baru mencapai 63,16\%. Karena harapan ketuntasan yang ingin dicapai dalam penelitian ini secara klasikal adalah 80\%, maka treatment dilanjutkan pada siklus II dengan topik "Expressing Compliments" dan “Expressing Opinions".

Pada siklus II, rata-rata hasil belajar Bahasa Inggris siswa adalah 7,61 dengan ketuntasan $86,84 \%$. Hal ini berarti adanya peningkatan baik dari rata-rata hasil belajar maupun ketuntasan klasikal. Dengan demikian, kriteria hasil belajar Bahasa Inggris siswa baik dilihat dari KKM sebesar 7,2 maupun ketuntasan klasikal sebesar $80 \%$ telah terpenuhi.

\section{Pembahasan}

Meningkatnya hasil belajar Bahasa Inggris siswa tidak terlepas dari model pembelajaran Think Pair Shareyang merupakan salah satu pembelajaran kooperatif berbasis teori konstruktivisme. Teori konstruktivisme menyatakan 
bahwa siswa harus menemukan sendiri dan mentransformasikan informasi kompleks, mengecek informasi baru dengan aturan-aturan lama dan merevisinya apabila aturan-aturan itu tidak lagi sesuai. Dengan demikian, siswa benar-benar memahami dan menerapkan pengetahuan di samping harus bekerja memecahkan masalah dan menemukan segala sesuatu untuk dirinya.

Dengan penerapan model pembelajaran Think Pair Share yang disebutkan Fogarty dan Robin (1996) siswa dilatih untuk banyak berpikir dan saling tukar pendapat baik dengan teman sebangku ataupun dengan teman sekelas, sehingga dapat meningkatkan hasil belajar ranah kognitif siswa karena siswa dituntut untuk mengikuti proses pembelajaran agar dapat menjawab setiap pertanyaan dan berdiskusi. Dalam proses berpikir tersebut, perlu penyisipan komik yang menimbulkan rasa nyaman dan senang. Rasa nyaman dan senang tentunya mengurangi ketakutan dan kekawatiran dalam menyampaikan ide-ide dalam melatih keterampilan berbicara.

Berdasarkan sintaks pembelajaran yang dikembangkan, model pembelajaran Think Pair Shareini memiliki tahapan yang memiliki kelebihan tersendiri. Pada tahap "think", siswa mendapat kesempatan waktu berpikir atau "thinking time" untuk memikirkan jawaban mereka sendiri sebelum pertanyaan yang diajukan dijawab oleh siswa lain. Hal ini akan mengurangi resiko siswa mengobrol, karena tiap siswa memiliki tugas untuk dikerjakan sendiri. Pada tahap "pair", siswa memperoleh kesempatan untuk berinteraksi satu sama lain dan mendiskusikan jawaban yang dimiliki masing-masing siswa. Tahap bertukar pikiran ini sangat diharapkan untuk memperkuat proses konstruksi pengetahuan. Tahap "share" adalah tahap final dimana siswa belajar mendengar presentasi tiap-tiap kelompok dan memberikan pendapat bila ada permasalahan yang perlu dipecahkan.

Namun demikian, selama proses pembelajaran berlangsung ternyata ada kendala-kendala, seperti: 1) ada beberapa siswa yang belum terbiasa dengan model pembelajaran Think Pair Sharebermedia komik pada siklus I sehingga berdampak pada kebingungan siswa dalam proses pembelajaran; 2) dalam pembelajaran yang dilakukan secara kooperatif baik itu pada tahap pair dan share masih didominasi oleh siswa yang lebih pintar sehingga bertentangan dengan 
tujuan awal pembelajaran yang bertujuan untuk meningkatkan hasil belajar Bahasa Inggris seluruh siswa kelas XI UPW A SMK Negeri 1 Singaraja; dan 3) hanya beberapa siswa yang mau serius dalam mengikuti proses pembelajaran, sementara yang lainnya kurang bisa berkonsentrasi. Dengan adanya kendalakendala tersebut, peneliti berupaya memperbaikinya pada siklus II dengan langkah-langkah, yaitu: 1) untuk mengatasi kendala yang pertama, guru menjelaskan lebih detail manfaat dan hasil yang akan diperoleh bila mengikuti model pembelajaran Think Pair Sharebermedia komik ini; 2) untuk mengindari pengelompokan yang didominasi oleh siswa yang lebih pintar, guru mengacak tempat duduk siswa dan mengupayakan penilaian yang memotivasi siswa yang kurang pintar untuk lebih aktif dalam proses pembelajaran; dan 3) untuk membuat siswa lebih berkonsentrasi dalam proses pembelajaran, guru mengajukan pertanyaan yang dirangsang dengan pemberian reward berupa nilai tambahan yang akan diakumulasi di akhir semester. Pemberian reward atau penghargaan tidak hanya berupa nilai akan tetapi bisa berupa sanjungan sehingga siswa merasa dihargai dan bisa fokus pada pembelajaran.

Adanya peningkatan pada hasil belajar Bahasa Inggris siswa dan motivasi berprestasi siswa melalui penerapan model pembelajaran Think Pair Sharebermedia komik merupakan kesuksesan dan kesesuaian antara teori yang ada dengan apa yang terjadi di lapangan. Hal ini didukung oleh Sudjana dan Rivai (2005) yang menyatakan bahwa komik adalah suatu bentuk kartun yang mengungkapkan karakter dan memerankan suatu cerita dalam urutan yang erat dihubungkan dengan gambar untuk memberikan hiburan kepada para pembacanya.

\section{Simpulan dan saran}

Berdasarkan hasil penelitian dan pembahasan terkait dengan penerapan model pembelajaran Think Pair Sharebermedia komik untuk meningkatkan hasil belajar Bahasa Inggris dan motivasi berprestasi siswa pada siswa kelas XI UPW A SMK Negeri 1 Singaraja, maka dapat disimpulkan (1) model pembelajaran Think Pair Sharebermedia komik mampu meningkatkan hasil belajar Bahasa Inggris siswa, dan (2) model pembelajaran Think Pair Sharebermedia komik mampu 
meningkatkan motivasi berprestasi siswa. Selanjutnya, ada beberapa saran yang bisa dijadikan sebagai bahan untuk perbaikan selanjutnya, sebagai berikut. (1) Kepada guru Bahasa Inggris agar mencoba menerapkan model pembelajaran Think Pair Sharebermedia komik sebagai upaya untuk meningkatkan hasil belajar Bahasa Inggris dan motivasi berprestasi siswa. (2) Penerapan model pembelajaran Think Pair Sharebermedia komik mungkin bisa dimodifikasi dengan model pembelajaran dan media yang lain sehingga mampu meningkatkan hasil belajar kognitif dan nonkognitif siswa. (3) Pemerintah, dalam hal ini Dinas Pendidikan Provinsi diharapkan dapat mensosialisasikan ke seluruh satuan pendidikan bahwa penggunaan media yang menarik bagi siswa, seperti komik, sangat membantu untuk motivasi berprestasi dan hasil belajar siswa.

\section{DAFTAR PUSTAKA}

Depdiknas. 2003. Undang-Undang Republik Indonesia No.20 Th.2003 Tentang Sistem Pendidikan Nasional. Jakarta: Depdiknas

Depdiknas. 2006. Permendiknas No 23 Tahun 2006. Diakses 13 September 2017.

Fogarty dan Robin. 1996. Think/Pair/Share. [Online]. Tersedia: www.Broward kl2.fl.us/Ci/Whatsnew/strategies and such/ strategies/thinkpairshare.html.Diakses 10 Januari 2017.

Huda, Miftahul. 2011. Cooperative Learning. Yogyakarta: Pustaka Belajar

Ibrahim, M. dan Mohamad Nur. 2000. Pengajaran Berdasarkan Masalah. Pusat Sains dan Matematika Sekolah. Program Pascasarjana UNESA: University Press

ILO (International labor Organization). 2012. Voices of youth: "Facing the global challenge on youth employment. [Online]. Tersedia: http://www.ilo.org/jakarta/info/public/pr/WCMS_176887/langen/index.h tm. Diakses 8 Januari 2017.

Kementerian Pendidikan Nasional. 2010. Peraturan Menteri Pendidikan Nasional Republik Indonesia Nomor 46 Tahun 2010 "Tentang Pelaksanaan Ujian Sekolah/Madrasah Dan Ujian Nasional Pada Sekolah Menengah Pertama/Madrasah Tsanawiyah, Sekolah Menengah Pertama Luar Biasa, Sekolah Menengah Atas/Madrasah Aliyah, Sekolah Menengah Atas Luar Biasa, Dan Sekolah Menengah Kejuruan Tahun Pelajaran 2010/2011". 
Lie, A. 2008. Cooverative Learning. Jakarta: Gramedia Widiasarana.

McClelland, D.C. 1987. Human Motivation. New York : Cambridge UniversityPress

Munthe, Rika Syahmewah dan Panjaitan,Keysar. 2016. Pengaruh Strategi Pembelajaran Dan Motivasi Berprestasi Terhadap Kemampuan Membaca Teks Naratif Bahasa Inggris Siswa Smp Negeri Di Kabupaten Labura.Jurnal Teknologi Pendidikan,.9 (1): 51-63

Ormrod, Jeanne Ellis. 2008. Psikologi Pendidikan Membantu Siswa Tumbuh Dan Berkembang Edisi Keenam Jilid 2. Jakarta: Erlangga.

Purwanto, Ngalin. 2004. Psikologi Pendidikan. Bandung: Rosda Karya.

Rochmad \&Sugiharti, Endang. 2015.TPS Application Based On Mouse Mischieffor Improving The Ability To Solvemathematicsproblem For Senior High School Studentsin Temanggung -Indonesia. International Journal of Education and Research, 3 (3): 331-338

Sudjana, Nana dan Rivai, Ahmad. 2007. Teknologi Pengajaran. Bandung: Sinar Baru Algesindo.

Sugiyono. 2009. Metode Penelitian Kuantitatif Kuantitatif dan R\&D (7th ed). Bandung: Alfabeta. 2009.

Syafii, Muhammad Lukman. 2018. Using The Think-Pair-Share Strategy To Increase Students' Active Involvement And To Improve Their Speaking Ability. IJEE (Indonesian Journal of English Education, 5 (1): 6180.doi:10.15408/ijee.v5i1.7679

Trianto. 2010. Mendesain Model Pembelajaran Inovatif-Progresif: Konsep, Landasan, dan Implementasinya pada Kurikulum Tingkat Satuan Pendidikan (KTSP). Jakarta: Kencana Prenada Media Group.

Trimo. 1997. Media Pendidikan. Jakarta: Depdikbud.

Utami, IGA Lokita P. 2011. The effect of Peer Assessment on Students' Writing Achievement with differing achievement motivation. Jurnal Ilmiah Pendidikan dan Pembelajaran,7 (2): 1-16

Winkle, W. S. 2004. Psikologi Pendidikan dan Evaluasi Belajar. Jakarta: PT.Gramedia Pustaka Utama. 